\title{
Give Them Their Rights: A Critical Review of Godfather and Godson Politics in Nigeria
}

\author{
Emma Chukwuemeka, Ph.D \\ Associate Professor/Head, \\ Department of Public Administration, \\ Nnamdi Azikiwe University, Awka Nigeria \\ Email: ee.chukwuemeka@unizik..edu.ng and hrvkonsult@yahoo.com \\ Tel: 08060967169 and 08052671039
}

\author{
R.O. Oji, PhD \\ Director, National Boundary Commission, \\ Maitama Abuja, Nigeria \\ Chukwurah D.J.C \\ Lecturer, Department of Public Administration, \\ Nnamdi Azikiwe University, Awka.
}

\begin{abstract}
This study evaluated the extent godfather politics has contributed to instability in Nigeria with a view to preferring solution to the problems identified. Survey research method was adopted. Data collected through questionnaire were analyzed using Z-test. The findings revealed that the current political instability in Nigeria is a function of the politics of godfathrism, it also revealed that godfatherism is the mother of corruption in Nigeria. The politics of godfatherism has also introduced mediocrity in the public bureaucracy resulting from faulty and lopsided recruitment method. Based on these findings, some of the major recommendations include; that the National Orientation Agency should intensify efforts in the reorientation of the political actors and employers of labout in the public service to enable them know the shortcomings of godfather politics. The law makers should enact a law to prohibit godfather politics in Nigeria and offenders should be barred from participating in political activities in Nigeria. Same law should guide recruitment, posting and training in the bureaucracy.
\end{abstract}

Keywords: Godfather, politics, bureaucracy, corruption

\section{Introduction}

The concept of godfatherism is synonymous to intermediary, mentoring, benevolence, and support and sponsoring. In a political setting, the concept is an ideology that is championed on the belief that certain individuals possess considerable means to unilaterally determine who get a party's ticket to run for an election and who wins in the electoral contest. Gambo (2009) contends that godfathers are men who have the 'power' and influence to decide both who get nominated to context elections and who wins in the election. In this sense, Godfatherism means office seekers getting connected to an individual who is believed to have the ability to deliver a desired outcome in an electoral contest. It is the tradition for looking for a political father to help promote one's political aspiration. Bassey and Enetak (2008) conceptualized godfatherism to connote the power and influence of people who are politically relevant in deciding who gets nominated to contest elections and who eventually wins the election. Godfathers are highly politically mobile and can sway political support to the political party and/or candidate behind 
which they throw their political weight. Those that play godfatherism are known as godfathers while those who benefit from their benevolence are known as godsons. The advent of godfatherism in the Nigerian partisan politics dates back to the First Republic when leaders of the three major political parties (Northern Peoples Congress (NPC), Action Group (AG) and National Congress of Nigerian Citizens (NCNC) carefully and meticulously cultivated godsons that they were convinced would advance the well being of the citizens. According to Uzoamaka (2010), Ahmadu Bello of NPC, Nnamdi Azikiwe of the NCNC and Obafemi Awolowo of the AG were motivated to do so not to use godsons as surrogates to promote parochial interests, but to promote the developmental aspirations of the people. Unlike the present crop of political godfathers, the first generation godfathers were essentially benevolent and progressive because they did not abuse their status as godfathers by imposing frivolous demands on their godsons as it is the case today.

Literally godfathers are seen in Nigeria to be men who have the power personally to determine both who get nominated to contest elections and who wins in a state. Those who get employed in the Bureaucracy and those who get robust postings and deployments. There is no gainsaying that godfatherism is firmly established in all the scepter of Nigeria politics and bureaucracy. It has now come to be a guiding principle in contemporary Nigeria.

\section{Statement of the Problem}

There is nothing wrong with Nigerian land, climate, bureaucracy, political ideology and public policy or anything else. The problem is 'Nigerian factor' which ranges from corruption, poor policy implementation, and politics of balanced federalism, ethnicity, unwillingness or inability of the leaders to rise to the responsibility of their calling (Chukwuemeka, 2008). The problems are too numerous to mention. However the critical one that requires close examination is the politics of godfatherism. Enugu State like other Nigerian states is a place where godfatherism reigns supreme in both political power transfer and recruitment process especially in the Bureaucracy. For instance godfather Jim Nwobodo installed Dr. Chimaroke Nnamani his godson as Governor of Enugu State in 1999. Chimaroke Nnamani installed Sullivan Chime his godson as Governor of Enugu State in 2007. In the year 1992 when Dr. Okwesilieze Nwodo became the Governor of Enugu State, he introduced what he called 'triangular equilibrium (Ugwu, 2011).' He used this administrative concept to over bloat the Enugu State Civil Service with his godsons. When Dr. Chimaaroke Nnamani emerged as Governor in 1999, he also recruited all manner of people whether literate or not into the Enugu State Civil Service. Presently Sullivan Chime is the Governor of the State; he also ensured that his godsons are favoured both in political appointment and civil service recruitment. Godfatherism undoubtedly has created unnecessary lopsidedness in recruitment of staff in Enugu State. It has also bred mediocrity, poor performance and poor service delivery. The situation is not different at the local government level. Transfer of political power from an incumbent to a successor is also based on godfatherism.

In the light of the foregoing, the following research questions become pertinent:

(a) To what extent has the politics of godfatherism in Enugu State impacted negatively on service delivery? 
(b) To what extent has the politics of godfatherism resulted in mediocrity and political instability?

\section{Objectives of the Study}

(1) To ascertain the extent the politics of godfatherism has impacted negatively on service delivery

(2) To determine the extent the politics of godfatherism has resulted in mediocrity and political instability in Enugu State of Nigeria.

\section{Hypotheses}

(1) The politics of godfatherism has resulted in mediocrity and instability in Enugu State

(2) Poor service delivery has correlation with the politics of godfatherism

\section{Methodology}

The study area is Enugu State of Nigeria. Enugu State is one of the states in Nigeria created in 1992. Enugu State was chosen because of the high rate of godfatherism politics prevalent in the area.

The data for this study were gathered through the administration of questionnaire on the target groups in Enugu State who were in position to discuss the politics of godfatherism and the attendant havoc. The questionnaire was designed in dichotomous and multiple choice methods: agree, strongly agree, undecided, disagree and strongly disagree. The extent was measured from 1 to 5 as in Likert -scale, while 1 represents the least extent, 5 represent the highest extent.

The questionnaire's validity and reliability were determined through content validity and its reliability determined through a pilot survey of eight (8) political analysts in Enugu State. A split-half method was adopted and a reliability co-efficient of $73.82 \%$ was obtained. The data collected were analyzed using the mean score while the hypotheses were statistically tested with the Z-test statistical measure.

\section{Literature Review} The Concept of godfatherism

Ajayi (2005) contends that a 'godfather' is a kingmaker, boss, mentor, and principal, while godson is the beneficiary and recipient of the legacy of a godfather. A godfather is some one who has built unimaginable respect and followers in the community, and possessed a well-organized political platform, and general acceptance from all and sundry. Ayoade (2007) argues that godfatherism, in its simple form is a term used to describe the relationship between a godfather and godson. Godfathers are slightly different from mafia and election sponsors. Mafianism in 
politics consists of formidable powerful blocs that have tremendous influence in the society that is, the Kaduna Mafia (Bala and Tyoden, 1987). It comprises of coalition of strong socioeconomic and political elites that share similar value system, and under an organized structure. In most cases, there are always godfathers who control the affairs of the mafia. Godfathers are powerful individuals who determine who, what, when and how, in the corridors of power and employment in the bureaucracy. Many godfathers in the present-day Nigeria operates like the mafia by displaying similar violent scheming and aggressive politicking, coupled with manipulating devices of having their way by any means. They rely on Machiavelli's slogan, 'the end justifies the means'.

Godfathers reign across all spheres of the society: academics, legal and religion environments. There are professors who determine who joins the academia. The relationship between godfather and godson in employment and politics claims the monopolitistic use of the term godfatherism; the 'ism' makes it political. Godfatherism thrives across the globe. There is hardly any state devoid of the existence and influence of godfathers, though the level of such influence varies. In America, the political candidates wiggle around seeking group and individual endorsements for their candidacy. Also in other advanced countries, group influence and endorsement could be more valuable than a powerful individual (Ajayi, 2005). The fact remains that prominent members of the society still influence the recruitment process either into the bureaucracy or political office.

\section{Tracing the roots of godfatherism in Nigeria}

The origin of godfatherism in Nigeria could be traced according to Udo (2011) to christianity where godparents are chosen as surrogates to help biological (or adopted) parents raised christian to become God fearing and law-abiding adults. Many people had Godparents that helped to shape their moral development and some whose parents died early were raised by their godfathers. Robin (2010) also traced the origin of godfatherism in politics to the city of Chicago in the United States of America in the pre-world war II era, 'when the heads of criminal gangs sponsored politicians in elections, manipulated the results to get them elected and, in turn, received protection and contracts from their political godsons".

The advent of godfatherism in the Nigerian bureaucracy and partisan politics dates back to the first republic when leaders of the three main political parties (Northern Peoples Congress (NPC), Action Group (AG) and National Congress of Nigerian Citizens (NCNC) carefully and meticulously cultivated godsons that they were convinced would advance the well being of the citizens. According to Egboh (2009) Sir, Ahmadu Bello of the NPC, Dr, Nnamdi Azikiwe of the NCNC and Chief Obafemi Awolowo of the AG were motivated to do so not to use godsons as surrogates to promote parochial interests, but to promote the developmental aspirations of the people. Unlike the present crop of political godfathers, the first generation godfathers were essentially benevolent and progressive because they did not abuse their status as godfathers by imposing frivolous demands on their godsons whom they provided employment or political space as it is the case today. They served as a huge reservoir of wisdom and experience to be consulted on the business of governance. Indeed, in a relative sense, the first generation godfathers were drawn by community sense of interest in seeking to influence political selection and employment into the public bureaucracy or seeking to influence the electorates to vote for some candidates of their choice. It was enough satisfaction for them that they wielded 
tremendous influence in the society and this inevitably generated a groundswell of goodwill and reverence for them as their views on political issues were scarcely contested in their respective regions of the Country. Corroborating the benevolence of the first generation godfathers, Ekezie (2009) argues that, understanding the role of politics as well as the military in an evolving country., Sir, Ahmadu Bello placed his godchildren in viable institutions and the rewards to the Northern Nigeria are today self-evidence; Chief Obafemi Awolowo was godfather to a large number of today's Yoruba intelligentsia that have applied his teachings for the benefit of their region; also within the Ibo community, the late Sir Odumegwu Ojukwu, was godfather to Dr. Nnamdi Azikiwe who rose to become the first Premier of the old Eastern Region and later emerged the first President of Nigeria under the defunct parliamentary arrangement.

\section{Godfatherism in Nigerian Public Administration}

Godfatherism is a common phenomenon and a concept that is very popular in recruitment process in the Nigerian Public Administration. It also cuts across promotion, deployment and posting exercises. Godfatherism in recruitment process as variously described by many scholars such as Okoro (2010), Chukwuemeka, (2010) and Ude (2008) involves the interference of the godfather in recruitment process to ensure that his godson is recruited whether qualified or not. To a large extent this has resulted in flooding the public bureaucracy with unqualified staff. Godfatherism goes beyond micro level to macro. It is macro when the government interferes on behalf of the people who have 'Abrahams' as father in the government. Ego (2012) argues that faulty recruitment includes the government interference in recruitment practices, favoritism, geographical spread or triangular equilibrium. However quota system or geographical spread/triangular equilibrium agreed is a regular feature in the recruitment process across the public bureaucracy in Nigeria, especially in Enugu State.

Adebayo (1995) sees godfatherism in recruitment process as unhealthy for the public bureaucracy. According to him faulty recruitment results to poor service delivery being recorded in the bureaucracy across the Country. Adebayo (1995) also argues that Nigeria public service is characterized by the recruitment of mediocre or totally unsuitable candidates in preference to candidates of high merit. . He is wont to describe godfatherism as nepotism and corruption

Ajadike (2010) views the idea of applying 'man-know-man' (godfatherism) principle in promotion, conversion of staff and training as awful and also a bad administrative practice which has affected Nigeria sustainable development. Chukwuemeka (2008) also contends that there are many other factors that are synonymous to godfatherism but still impede on efficient performance and service delivery. They are nepotism, party affiliation and bribery. Normally an organization should strive to make sure that it recruits the right caliber of personnel by maintaining a partial free recruitment policy.

To ensure that this works, there should be strict supervision of each ministry by high powered independent body to be set by the State.

\section{Godfatherism and Politics in Nigeria - A reexamination:}

Godfatherism is not only prevalent in recruitment process in the bureaucracy; it is also a common phenomenon in Nigerian democratic process. It is not common for a political office 
seeker in Nigeria not to have a godfather. The godfather and godson contradictions have resulted to severe crisis across many Nigerian federating units.

\section{The Anambra State Experience}

Anambra Statre is one of the federating units in Nigeria that is popularly known for godfather politics. Between 1999 and 2003, the fight was between Emeka Offor (Godfather and the Governor of the State Chinwoke Mbadinuju (godson), who refused to dance to the tune of the godfather. This led to Mbadinuju;s loosing the gubernatorial ticket for Peoples Democratic Party (PDP) and his subsequent inability to buy political space in 2003 . The dust raised by these to political bigwigs was yet to settle when two other actors emerged, Chirs Uba and Chris Ngige. Uba was the godfather responsible for the installation of Ngige. Ngige pledged his loyalty to Uba and assured him of cooperation. Based on this Uba bankrolled the generational election to the tune of three billion naira. After the election, Ngige refused to pay back his godfather the necessary commission and patronage. And what supposed to be a cold war was made public with the abduction of Ngige and his purported resignation. Since then, peace has eluded the State until Ngige was defeated at the election petition tribunal for rigging the gubernatorial polls by the All Progressive Grand Alliance (APGA) candidate Mr. Peter Obi.

\section{The Kware State Experience}

Between 1999 and 2003, the battle line in Kwara politics was well defined. Olusola Saraki, former Senate leader and political kingpin, was in contest for relevance with his former protégé, Mohamed Lawal, a retired Navy Commodore, who was the Governor of the State then. Saraki, who has installed not less than four governors in the State, including Lawal, himself, fell out with Lawal on the sharing of political booties. But Lawal did not compromise and these led to a cold war which culminated in the expulsion of Saraki from the then All People's Party (APP), now All Nigerian People's Party (ANPP) and Saraki teamed up with People's Democratic Party (PDP) in the State. Then, the 2003 elections to both men was the ultimate battle to determine the political grandmaster of the State. They deployed their vast resources to prosecute the 'war'. During this 'war' bomb blasts shattered the peace of Ilorin, this happened at the premises of National Pilot Newspaper owned by the Saraki's . Lots of people were assassinated, maimed, injured, etc. during the imbroglio.

\section{The Enugu State Experience}

Between 1999 and 2010, the godfather and godson battle was between Chief Jim Nwobodo and Dr. Chimaroke Nnamani. Nwobodo installed Nnamani. Nnamani could not settle Nwobodo and the two fell apart. Between 2007 and 2010 the godfather-godson battle was between former Governor Chimoroke Nnamani and Governor Sullivan Chime. Chimoroke played godfather to Chime during the 2007 gubernatorial election. He did all that were humanly possible to install Chime as the Governor of Enugu State. As soon as Governor Chime emerged, Nnamani sent a long list of potential political appointees to Chime and also demanded to remote control the leadership of the State. This did not go well with Chime and they fell headlong. Chime used his 
power of incumbency to outwit him and formed his government. Up till today the 'war' has not ended. Ndubuisi (2011) argues that Enugu State has lost huge sums of money that would have been used to develop the state to settle godfathers; many of them were directly or indirectly involved in installing governors and chairmen of local governments. Ndubuisi (2011) also argues that the high level of political instability in Enugu State today is as a result of the activities of godfathers.

\section{Implications of the politics of godfatherism on governance}

In Nigeria's fourth republic, the emergence of godfatherism posed great threat not only to good governance but also the socio-economic stability of democratic governance. Perhaps one of the most disturbing and damaging influence of godfatherism in Nigeria's fourth republic was in domain of making nonsense of a truly free, fair and credible electoral process in which the electorates by right are expected to freely elect people of their choice into public office to represent their interests. Indeed, the privilege of electing people of their choice into public office was denied given the situation in which godfathers foisted candidates of their preference on the generality of the people. This is to say the least very inimical to the tenets of democratic rule.

When public office holders would not be accountable to the people, who at any rate did not count in their elections into public office. Invariably, the loyalty of such public office holders would be tilted towards their godfathers and this in itself negates one of the critical attributes of democracy which is responsive and transparent government. This scenario is also inimical to good governance and political stability which are predicated on the rule of law, due process, accountability and transparency in the management of public business. The emergence of godfatherism has also robbed the citizens of the privilege of enjoying the dividends of democratic governance in the sense that the- would be government became reluctant to initiate and implement policies that would advance the wellbeing of the generality of the citizens. This was as a result of the fact that godfatherism in Nigeria was basically predatory in nature. The primary motive of venturing into politics was borne out of the need to acquire money from the coffers of government to which their godsons held sway. Therefore the lean financial resource accruable to the state from the federation account which was meant for the improvement of living standard of the citizens was paramount interest to them. In instances where the godsons upon reflection refused to settle their godfathers as agreed upon before securing public office, hell was let loose. The experiences recorded in Enugu State in 1999 between Jim Nwobodo and Governor Chimaroke Nnamani. Also in 2007 between Governor Sullivan Chime and Chimaroke Nnamani were awful.

Another far reaching implications of godfatherism on the entrenchment of good governance, which in turn would engender democratic growth and stability, according to Uduji (2009) is the complete erosion of the normative elements of democracy of which trusts is a sine-qua-non attribute between the government and the governed. In a polity where prescribed rules guiding the electoral process are frequently disobeyed with impunity, the basis of citizen's trust in government was compromised. If the situation is not decisively addressed with the urgency it deserves, the resultant effect is that trust as a vital social capital is lost, and when there is no trust between the government and the governed, interaction would only take place on the basis of 
mutual suspicion and this does not augur well for the healthy development of democratic governance.

\section{Test of Hypotheses 1}

H1 - The politics of godfatherism has resulted in mediocrity and instability in Enugu State

Ho - The politics of godfatherism has not resulted in mediocrity and instability in Enugu State.

Table 1: The high rate of mediocrity and instability in the governance and public service is as a result of godfatherism

\begin{tabular}{|l|l|l|l|}
\hline & Yes & N o & Total \\
\hline No of respondents & 39 & 18 & 57 \\
\hline Proportion & $0.68\left(\mathrm{P}_{1}\right)$ & $0.32\left(\mathrm{P}_{2}\right)$ & 1.00 \\
\hline
\end{tabular}

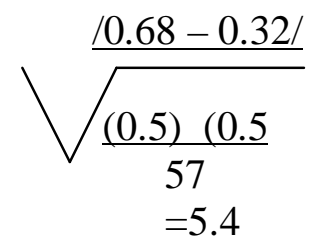

Using the normal distribution table at $\mathrm{a}=0.05$, the tabulated $\mathrm{Z}-$ value is 1.645 , hence one-tailed test for equality of the two ;proportion (i.e. Ho) is rejected in favour of H1.Conclusion therefore, is that $\mathrm{P}_{1}$ is significantly greater than $\mathrm{P}_{2}$

Decision - Since the value of $Z$ - calculated is greater than the value of $Z$ - tabulated, the Ho is rejected.

Conclusion: $\mathrm{P}_{1}$ is significantly greater than $\mathrm{P}_{2}$ which means that the politics of godfatherism has resulted in mediocrity and instability in Nigeria..

\section{Hypothesis 2}

H1- Poor service delivery is has correlation with the politics of godfatherism Ho - Poor service delivery has no correlation with the politics of godfatherism

Table 2: In view of the politics of godfatherism prevalent in Nigeria especially in Enugu State service delivery has been very low.

\begin{tabular}{|l|l|l|l|l|l|}
\hline & $\begin{array}{l}\text { Strongly } \\
\text { agree }\end{array}$ & Agree & Disagree & Not sure & Total \\
\hline
\end{tabular}




\begin{tabular}{|l|l|l|l|l|l|}
\hline $\begin{array}{l}\text { No of } \\
\text { respondents }\end{array}$ & 28 & 19 & 7 & 3 & 57 \\
\hline Proportion & 0.5 & 0.33 & 0.13 & 0.04 & 1.00 \\
\hline & & & & & \\
\hline
\end{tabular}

Since there are four responses, the natural thing is to assume, under Ho that the proportion of responses are equal, hence assumption is that $\mathrm{P}=0.25$.

$\mathrm{P}_{1}=0.5, \mathrm{P}_{2}=0.33, \mathrm{P}_{3}=0.13$ and $\mathrm{P}_{4}=0.04$ and compare them each with the population proportion of $\mathrm{P}=0.25$.

For 'Strongly agree'

Ho: the proportion of $\mathrm{P}_{1}$ is 0.25 (i.e. $\mathrm{P}_{1}=\mathrm{p}$ )

$\mathrm{H} 1: \mathrm{P}$ is not equal to 0.25 (i.e. $\mathrm{P}_{1}=\mathrm{P}$ )

Test statistics $\mathrm{Z}$, since sample size is large (i.e>30)

So $\quad / \mathrm{P}_{1}-\mathrm{P} /$

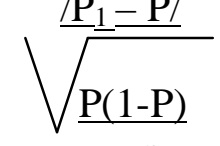

$\mathrm{n}$

$$
=\frac{/ 0.5-0.251 /}{\sqrt{\frac{(0.25)(0.75)}{56}}}=4.32
$$

For $\alpha=0.05$, for a two-tailed test, $\mathrm{Z}$ from the normal distribution table is 1.96 .

Decision: - Since the calculated Z (4.32) is greater than the tabulated Z (1.96), Ho is rejected. Conclusion therefore is $\mathrm{P}_{1 \neq} \mathrm{P}$ hence, sufficient evidence abound that the proportion of respondents who strongly agree is significantly greater than 0.25 .

There is also need to test 'Agree' responses for significant difference from $\mathrm{P}_{1}=0.05$

The procedure is to carry on as before'

$\mathrm{Z}$

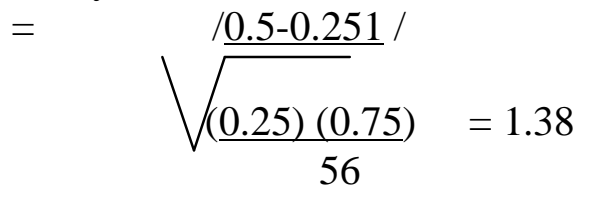

For $\alpha=0.05$, the tabulated $Z=$ value is 1.96 . Since $Z=-$ calculated is 1.38 which is less than $1.96 \mathrm{~m}$ Ho is accepted. Conclusion is that the proportion who agree to the opinion is not significantly higher than 0.25 .

For 'disagrees' and 'Not sure' opinions, it can be seen that the figures are very small. Considering the result from 0.33 figures an inference can be made that the outcome of the 'disagree' and 'not sure' opinions will not be significantly higher than 0.25 . And this will amount to testing the obvious. 


\section{Findings}

The study revealed the following:

(a) That political instability is a function of godfatherism

(b) Mediocrity which is inherent in governance and public bureaucracy is also a function of godfatherism in politics.

(c) The activities of godfathers have negative effect on socio-economic development of Enugu State and of course the entire nation.

(d) The study also revealed that godfatherism is the mother of corruption

(e) The study has also shown that political godfatherism has robbed the citizens of the privilege of enjoying the dividends of democratic governance.

\section{Recommendations and conclusion}

The following recommendations are proffered:

(a) The National Orientation Agency should intensify efforts in the reorientation of the politicians and the employers of labour in the public bureaucracy to enable them know the evils inherent in the politics of godfatherism.

(b) Less emphasis should be placed on money for those seeking political office, rather emphasis should be placed on the credibility of the candidate seeking political office.

(c) The law makers should enact a law to prohibit godfather-politics in Nigeria; offenders should be barred from political activities in Nigeria. The same law should also apply to guide recruitment, posting and training in the bureaucracy.

We therefore conclude that unless godfatherism is stamped out of Nigerian politics, it would be difficult for Nigeria to be stable in politics and democratic governance.

\section{References}

Adebayo, A (1995) Principles and Practice of Public Administration in Nigeria, Ibadan: Spectrum Books

Ajadike, U (2010) The Politics of Gofatherism in Nigeria, Journal of Policy and Development Studies, 5(2) 25-31

Ajayi, F.S (2006) Nigerian Political godfatherism in the world of Baale Molete, Nigeria world (online) January 20, pp.1-7

Ayodele J (2007) Godfather politics in Nigeria, Journal of Political Science, 2(3) 50-59

Bala F and Tyoden S (1987) Political parties and pressure groups, in Anifowose, Remi and Enemuo, F (Eds.) Elements of Politics, Lagos: Sam Ironsi Publishers 
Bassey,N and Edet, E (2008) Godfatherism and good governance in Nigeria: An appraisal of Nigeria's fourth republic, Journal of Social and Policy Issues, 5(3) 120-130

Chukeuwmeka, E (2008) Administration and Politics in Nigeria, Past, Present and Issues, Lagos: Vinez Publishers.

Chukwuemeka, E (2010) Democratisation in a praetorian Polity: The Nigerian Experience, Journal of the Management Sciences, 6(7) 49-60

Egboh, E (2009) Niger Delta Youth Reseiveness and Socio Economic Development of Nigeria, International Journal of Sustainable Development, 1(1) 55-61

Ekezie, N (2009) Repositioning Nigeria for future politics, Journal of Policy and Development Studies, 4(1) 23-30

Ego, S (2012) The politics of sit tight leadership in Nigeria, Journal of Politics, 1(1) 33-40

Gambo, A (2009) Godfatherism:Menace to democracy, Journal of Social Studies, 1(1) 25-33

Ndubuisi, J (2011) Politics in Nigeria: An Appraisal, Enugu: HRV Publishers

Okoro, P (2010) The Substance of Social Studies: The Nigerian Perspective, Lagos: Vinez Publishers.

Robin, U (2010) International politics: A Contemporary Approach, Ghana: ETC Books.

Udo, O (2011) Money politics in Nigeria: the way forward, International Journal of Sustainable Development, 1(1) 30-38 
Ude, S (2009) Trends in Public Management, Enugu: HRV Publishers.

Ugwu, W (2011) An empirical study of leadership and governance in Nigeria Journal of Policy and Development Studies, 4(2) 33-40

Uduji, P (2009) Introduction to Political Science, Enugu: Wayas Publishers

Uzoamaka, G (2010) The role of Government in poverty reduction,

Journal of Political Science, 1(2) 33-41 